Univerzita Mateja Bela v Banskej Bystrici

gabriel.rozai@umb.sk

\title{
VPLYV MULTIKULTÚRNOSTI NA PODOBU LOKÁLNEJ TOPONYMIE (NA PRÍKLADE PIATICH VÝCHODOGEMERSKÝCH OBCÍ)
}

K l’ú č o vé s lo vá: živá toponymia, nemecká banská kolonizácia, valaská kolonizácia, slovensko-mad'arské jazykové kontakty, východný Gemer

V príspevku venujeme pozornost' neštandardizovanej toponymii piatich obcí východného Gemera. Ciel’om nášho príspevku je analyzovat' terénne názvy, ktorých lexikálno-sémantická stránka odkazuje na koexistenciu rôznych etník (so svojimi jazykovými, kultúrnymi a hospodárskymi špecifikami) v rámci historického vývinu severnej časti Slanskej doliny. Gemerský región predstavoval významnú kultúrnu a hospodársku oblast' bývalého Uhorska, bol „kolískou“ uhorského baníctva železných rúd, ako aj priestorom charakterizovaným etnickou, jazykovou a náboženskou rozmanitost’ou. Multikultúrny charakter tohto regiónu podnecovalo viacero faktorov, a to najmä osobitosti historického vývinu (tatárske, turecké vpády a i.), hospodárska politika gem. šlachtických rodov, poloha regiónu v rámci Uhorska, pestrá geomorfológia, prírodné a nerastné zdroje, úzke väzby medzi čast’ou hospodárskych aktivít a etnickým charakterom ich vykonávatel’ov či vzájomná (surovinová a iná) podmienenost' niektorých hospodárskych odvetví. V rámci analýzy sa zameriavame na prítomnost' najvýznamnejších (neslovenských) etnických skupín determinujúcich hospodársky, kultúrny a jazykový charakter gemerského regiónu, a to na nemecké a mad'arské etnikum a na etnicky rôznorodý valaský živel.

Skúmanú oblast' tvoria obce ležiace v severozápadnej a severnej časti Slanskej doliny: Rejdová (d’alej aj R), Vyšná Slaná (VS), Vlachovo (Vl), Gočovo (G) a Nižná Slaná (NS). Z hl'adiska historického vývinu možno za najstaršie obce pokladat' pôvodom banícke osady Vyšná Slaná (1. oficiálna zmienka o obci je z roku 1362) a Nižná Slaná (1363). Baníctvo ako hlavný zdroj obživy spočiatku dominovalo aj vo Vlachove, ktoré bolo v 15. stor. dosídlené valaským obyvatel'stvom. Valasi sa však usadili aj v ostatných banských obciach. Rejdová sa prvýkrát spomína až v roku 1551 ako obec vzniknutá na valaskom práve. Pastierskou obcou bolo aj Gočovo (s prvou 
písomnou zmienkou z roku 1427), hoci valaské výsady mala iba čast' pôvodného obyvatel'stva. Do hospodárskej štruktúry týchto pastierskych obcí sa postupne začlenilo aj baníctvo a hutníctvo (Šüle, Šüle ml. 2005).

Do štúdie sme zahrnuli terénne názvy získané terénnym výskumom. Pri názvoch s menej priezračnou etymológiou (na mysli máme najmä čast' názvov kategórie 1.1. a čiastočne aj kategórie 2 . v rámci prvej analyzovanej skupiny) uvádzame aj vybrané historické podoby názvu získané archívnym výskumom a excerpciou bibliografických a kartografických zdrojov zachytávajúcich historickú toponymiu ${ }^{1}$, ktoré nám môžu pomôct' pri rekonštrukcii (predpokladaného) pôvodného lexikálneho významu slova využitého pri vzniku propria. Názvy, ktorých inojazyčný pôvod sa nám na základe doterajšieho výskumu nepodarilo hodnoverne preukázat', sme do príspevku nezaradili.

S ciel'om sprehl'adnit' a štrukturalizovat' analyzovaný materiál kategorizujeme terénne názvy do niekol'kých skupín. Jazykový odraz kontaktov s jednotlivými etnikami umožňuje utváranie rôznych kategórií terénnych názvov. Ich vzájomnou komparáciou však dospievame $\mathrm{k}$ istým spoločným črtám tvoriacim základné body klasifikácie, ktoré možno v rámci zvolených výskumných okruhov d’alej špecifikovat'. Základná kategorizačná štruktúra (reflektujúca okrem lexikálno-sémantických aspektov aj jazykovozemepisné hl'adisko a kontakty medzi onymickými sústavami) má nasledujúcu podobu:

1. Terénne názvy utvorené z apelatívnej lexiky nedomáceho (nem., mad', rum. a i.) pôvodu, resp. z lexiky charakteristickej pre daný kolonizačný pohyb.

2. Terénne názvy utvorené z antroponým nedomáceho pôvodu, resp. antroponým odkazujúcich na nedomáce (neslovenské) etnikum; k daným terénnym názvom však pristupujeme ako k nepriamym dôkazom o prítomnosti skúmaných etník, na čo osobitne upozorňujeme v časti venovanej valaskej kolonizácii.

3. Terénne názvy súvisiace s apelatívnou lexikou domáceho pôvodu, ktorá svojím významom priamo odkazuje na hospodárske aktivity či prítomnost' skúmaných etník v danej oblasti.

\section{ODRAZ NEMECKEJ BANSKEJ KOLONIZÁCIE V MIESTNEJ TOPONYMII}

O úplných počiatkoch banskej činnosti na Gemeri niet presných údajov, možno však predpokladat', že siahajú do obdobia raného osídl'ovania regiónu. Prvé písomné správy o osídlení severovýchodného Gemera však pochádzajú až z 2. polovice 13. stor. (Marsina 1991). Centrom našej pozornosti sa teda stáva nemecká banská kolonizácia Uhorska, ktorá začala v 12.-13. stor. a súvisela s podporou hospodársky

\footnotetext{
${ }^{1}$ Historické podoby terénnych názvov sme získali excerpciou zdrojov Protocolon Petschelianum (1670-1713), Protocollum Visitationis Ecclesiarum Canonice (1802-1804), II. vojenské mapovanie (1806-1869) a Gömör megye (Ila 1944, 1946).
} 
oslabenej krajiny po tatárskych vpádoch. Prvé osídl'ovanie severnej časti Slanskej doliny nem. kolonistami možno datovat' približne do 2. polovice 13. storočia. Ich prítomnost' sa spomína v stredisku banského podnikania východného Gemera v Dobšinej. Podl'a M. Horváthovej (2002) potvrdzuje túto skutočnost' aj listina král'a Ladislava IV. dobšinskému hlavnému županovi Hekkulovi z roku 1284, poukazujúca na usídlenie sa Nemcov a používanie nemeckého práva. Na významné zastúpenie nem. etnika v Dobšinej odkazuje aj existencia samostatnej nem. nárečovej enklávy, tzv. bulejnerského nárečia.

Miestne terénne názvy spojené s nem. banskou kolonizáciou môžeme klasifikovat' nasledujúcim spôsobom:

\section{Terénne názvy utvorené z apelatívnej lexiky nemeckého pôvodu}

1.1. Lexémy, ktoré neprenikli do lexiky miestnych východogemerských nárečí. Z hl’adiska formálnej výstavby názvov dominujú v tejto podkategórii zložené názvy (dôraz kladieme na určovaný komponent; $v$ názvoch so zretel’nou sémantikou prvého komponentu odkazujúcou na nem. apel. lexiku vymedzujeme oba komponenty) utvorené z nem. apelatív $v^{2}$ :

-r Berg (perk/benk) 'hora, vrch' Ramperk NS (hist. Za ssrambergom (zem) prvý člen zloženého názvu naznačuje motiváciu vlastníctvom, t. j. o. m. *Šram ${ }^{3}+r$ Berg, resp. ide o stredohornonemecké apel. schram, dnes e Schramme 'jazva'; porovnajme aj český banský termín šramati 'podsekávat' uhol'nú vrstvu', nem. schrämen (Machek 1971)); Rimperk NS (hist. Pod rympergom; B. Ila (1944) uvádza etymológiu: o. m. Rim $+r$ Berg), Pod Rimpergom NS; Peterbenk VS (etym. o. m. Peter + $r$ Berg);

$r$ Hübel (hibel/hibel) 'kopec, vŕšok': Macíbel NS (hist. Maczibel, Matzhübel, etym. o. m. Macz, Matz (< Matthäus) + r Hübel), Za Macíblom, Pod Macíblom NS; Špedzhibel VS (hist. Spitzhübel, etym. spitz 'ostrý, špicatý' + r Hügel);

e Buche (Bux-) 'buk' a $r$ Wald (-ualt) 'les': Buxualt R;

$r$ Bär (bulejnersky pe:r/pear 'medved"' (Valiska 1980)) a r Grund ('dolina'; gem. grunt 'pozemok, základy' (Orlovský 1982)): Pärigrunt NS (hist. Perendgrunn, Pri pergrundu, Parigrund), t. j. 'Medvedia dolina';

e Fahrt (farc) 'cesta (dopravným prostriedkom)', 'banský rebrík': Šmelfarc Vl (hist. Ssmelfarc, Schnellfahrt; etym. Schmelz- (e Schmelze 'tavenie', schmelzen 'tavit') + e Fahrt, resp. Schnell 'rýchly' + e Fahrt);

2 Tieto lexémy sú vplyvom adaptačných procesov do štruktúry miestnych slovenských nárečí spojené s rôznymi formami hláskoslovnej a morfologickej adaptácie. Okrem toho v nich nachádzame aj niektoré prvky nem. bulejnerského nárečia, tie však vzhl’adom na rozsah príspevku bližšie neanalyzujeme.

${ }_{3}^{3}$ Porovnajme terénny názov Schramkova (z roku 1768) v chotári Gemerskej Polomy (Ila 1944). 
$r$ Zinnober (cinópel) 'rumelka': Cinópel Vl;

e Glatze 'plešina, lysina', resp. Glatz 'plešatý' (DWB 1971): Glac, Pod Glac NS;

$r$ Hag 'živý plot', resp. $r$ Hagen (spiš., nem.) 'pásy vŕb/trniek vysádzaných na ochranu lúk a polí'; v lesníckej terminológii však môže íst' aj o opačný význam, t. j. hacken (hágen) 'rúbat', sekat' (Pavlík, v: Štefaňak 2009: 23): Hágen/Hágne NS (hist. Hagen);

knöll mask. (*knol), v dialekte mesta Ruhla v Durínsku s významom 'kleiner aus einem höheren Berg vorspringender Hügel' (Regel 1868: 219): Knola NS.

1.2. Lexémy tvoriace súčast' lexiky miestnych nárečí s priamym odkazom na banskú a hutnícku činnost'. Zarad'ujeme sem názvy utvorené z apelatív: hámer/hamer ('hámor, väčšia dielňa na spracovanie železa kovaním obyčajne využívaním špeciálneho nástroja podobného väčšiemu kladivu', nem. $r$ Hammer 'kladivo, vel'ké strojové kladivo na spracúvanie kovov' (Krajčovič 2009)) > Hámer, Hámrik, Pod Hámrik, Za Hámrikom Vl, Do Hámre/-a NS, Do Hámra, Nad Hámrom G, Hamrisko, Nad hamer VS, Hamriska, Nad Hamriska, Za hamer R; huta ('závod na výrobu kovov z rúd, na ich d’alšie spracúvanie', nem. e Hütte) a hutni (adj.) > $\operatorname{Kar}(o)$ lová huta Vl, Na Hutu, Hutna cesta R; šaxta ('zvislá, hlboko pod povrch vyhíbená jama', nem. $r$ Schacht) > Frajšaxta/Frašaxta VS, Stará šaxta NS; halen (hálňa, 'hromada kamenia, najmä pred baňami, halda' (SSJ 1: 456), nem. e Halde) > Halen R. Určujúci člen dvojslovného názvu Štolärskie prị̂elohi NS (Štelärské prialohi (JÚLŠ́)) sa pravdepodobne utvoril z apel. šteliar 'majitel' hámru, hámorník', ktoré sa vytratilo zo súčasnej nárečovej lexiky, HSSJ 5 (2000: 666) ho však zaznamenáva aj v Gemeri. Slovník F. Š. Kotta (1906: 431) dokladá v češtine aj apel. štolar̆, t. j. baník 've štole pracující'.

1.3. Lexémy tvoriace súčast' lexiky vgem. nárečí bez priameho odkazu na banskú či hutnícku činnost'. Názvy tejto podskupiny sa utvorili z apelatív: šajba a i. (nem. e Scheibe 'kruh, koleso, obruč') > Na Šäjp G, Šéjba NS, Šajba VS (v tomto prípade išlo o lúku, na ktorej sa nachádzala strelnica so ‘šajbou', teda okrúhlym terčom (JÚLĽS); v súčasnej toponymii sa názov Šajba spája s tokom pretekajúcim daným objektom); kiar/kär ('zákruta', nem. e Kehre) > Kịar VS a pravdepodobne aj Kilärka NS, ako na to upozorňuje B. Ila (1944: 48), v tomto prípade však nemožno vylúčit' aj spojitost's o. m. Kiral, Kirall (doloženým napr. z Čiernej Lehoty (Ila 1944)); štreka ("železničná trat", nem. e Strecke) > Za štrekou G; baxterňa (gem. 'domček železničného strážnika' (Orlovský 1982: 21); z apel. baxter 'nočný strážnik', 'železničný strážnik', nem. $r$ Wächter) > Pri baxterni G; luós (lós, 'lístok alebo iný predmet ako prostriedok na náhodné rozhodnutie niečoho' (SSN 1: 87), prenesene 'pozemok získaný losovaním'; nem. s Los) > Luóse, Luósiki NS; tál (nár. '(malý) diel, čast' lúky') > Tále G; šop (šopa, 'podstrešie nad maštal'ou a drevárňou slúžiace na uskladnenie sena' (Orlovský 1982), nem. $r$ Schuppen) $>$ Ku šopu VS; fraj (gem. 'vol'ný' (Orlovský 1982), nem. frei) > Frajšaxta VS (šachta založená na dobrovol'nej práci baníkov); uoserzak ('vodojem', porovnaj- 
me vaserzág v Sirku (Orlovský 1982: 371), uoserzak v Rejdovej, tu s významom 'odtokový kanál na odvodnenie' (HSSJ 6: 307; v. v.), z nem. s Wassersack) > Uoserzak VS; rizen ('žl'ab, splav na dopravu dreva v horách', nem. e Riese) > Rizňouna dolinka/Do Rizni R.

\section{Terénne názvy utvorené z antroponým nemeckého pôvodu}

Ako uvádza J. Krško (2008), Nemci prichádzajúci na Slovensko mali status hostí spojený s osobitnými sociálno-právnymi výhodami, ktoré sa neskôr prejavili aj vo vlastníctve pôdy. Čast' antroponým zachytených v analyzovaných terénnych názvoch možno doložit' aj prostredníctvom archívnych dokumentov. Niektoré z nich sa však v dostupných súpisoch nezachovali. V skúmaných obciach sa môžeme stretnút' s nem. antroponymami už v najstarších obyvatel'ských zoznamoch (Ila 1944, 1946). Pre slovotvornú štruktúru väčšiny názvov utvorených z nem. osobných mien je charakteristický výskyt domácich formantov $-k a,-o v,-o v a^{4}$. Tieto formanty môžu do istej miery slúžit' aj ako pomocný prostriedok pri odhal'ovaní sémantiky niektorých nejasných názvov.

Do tejto kategórie sme zaradili terénne názvy Bartlová NS (z o. m. Bartel zachyteného v Dobšinej v roku 1575 (Ila 1944)); Fafl'ouna R (pravdepodobne z o. m. *Fafl, v súčasnosti známeho v Ružomberku (Ďrurč i in. 1998)); Gample NS, G (hist. Gempli 5 , Gample D.; z o. m. Gempel (Ila 1944; Sičáková 1996)), porovnajme aj hydronymum Gampel (zachytené aj v podobe Gampel potok) NS; Harmanová NS (z o. m. *Harman, bez dokladov v skúmanej oblasti); Järšmitka NS (hist. Jarsnitka; Farschmidtka (Žilák 1980); nejasná etym.: názov môže byt' utvorený z o. m. Schmied, napr. Kouach Smid (Ila 1944); variant Farschmidtka môže odkazovat' aj na o. m. Fahrschmied, v apel. význame 'vojenský kováč', porovnajme meno domu Do Faršnidou (Babiná, okr. Zvolen)); LangoferoualLangoferka VS (z o. m. Langhoffer); Mixlou V1 (z o. m. Michael (Ila 1944), nem. hypok. *Michl; porovnajme o. m. GrozMichel > Grosmichl v Nižnej Slanej (Ila 1944)), Pod Mixlou, Mixlovec Vl; Plejzouna R (porovnajme názov Plezová v chotári Dobšinej; zrejme z o. m. *Plez, Plecz (Ila 1944)); Šingrejtloua VS (hist. Schingertova, Singertlova hora; z o. m. Schinger (Ila 1944), resp. *Schingert/Schingertl), Nat Šingrejtlounou VS; Štolcová NS (z o. m. Stolcz (Ila 1944), Štolc (bez dokladov v skúmanej oblasti)), Pot Štolcovó NS; U Švorci lúka G (z o. m. Svorcz (Ila 1944), v názve nachádzame meno domu U Švorci odkazujúce na vlastnícke vzt’ahy).

\footnotetext{
${ }^{4}$ Formant -ová vznikol substantivizáciou posesívnych adjektív so sufixom -ova po elipse druhového objektu.

5 Názov sa spomína v nasledujúcom kontexte: „Feketepataki kutnál, melyet Gemplianak hivnak“ (Ila 1944: 344).
} 
3. Terénne názvy utvorené z apelatív negermánskeho pôvodu priamo odkazujúcich na banskú činnost', resp. na prítomnost' nemeckého etnika

Na banskú a hutnícku činnost' odkazujú terénne názvy utvorené z lexém: baňa/bana, demin. banka ('zvislá jama vyhíbená do zeme s rozšírenou dolnou čast'ou, podzemná chodba na t’aženie úžitkových nerastov, rúd, uhlia' (Krajčovič 2007), psl. *banja) a banski (< baňa) > Šervená bana, Bana Simona Vl, Banka, Nad Bankó, Pod Bankó, Na bane, Nad baňoun, Za baňami, Pri baňoch NS, Pri baňi G, Ku Zlatej bani R, Majbova bana VS, Banská cesta, Banski potok (variant hydronyma Gampel potok), Stará banská cesta, Banské NS, Banskịe, Podbanskịe G; maša ('hutnícka pec'; nejasná etym.: môže íst' o mad'. zloženinu s mad'. vas 'železo, železný' typu vas-mü ‘železiareň' so zmenou $v>m$, resp. ide o skrátenie apel. mašina (z franc. machine) so sémantickým vývinom 'stroj' > 'výrobná prevádzka so strojmi' a pod. (Králik 2015: 349)) > Maša VS, Maša, Nad Mašó NS, Mašä Vl; rudní (< ruda 'hornina, z ktorej sa taví kov'; rus., ukr., pol'sky ruda, lat. raudus (Machek 1971)) > Rúdñié G, Rudnié NS; strịeberni (< striebro, psl. *sbrebro (Machek 1971)) > Strịeberňe R; na prítomnost' nem. etnika upozorn̆uje adj. nemeckí/nemecki (< etnonymum Nemec) $>$ Nemecka, Nemecki ban̆ R, Nemecká dolinka V1.

\section{VPLYV ETNICKY RÔZNORODEJ VALASKEJ KOLONIZÁCIE NA MIESTNU TOPONYMIU}

V oblasti Gemera zohrali významnú úlohu aj kultúrne styky s etnicky rôznorodým valaským živlom, ktorého prítomnost' podmieňovali vhodné prírodné podmienky na rozvoj salašníctva. Počiatky valaskej kolonizácie sa spájajú s územím rumunského Valašska, čoho dôkazom je apelatívna i propriálna lexika rum. pôvodu rozšírená predovšetkým v horských oblastiach Slovenska ${ }^{6}$. Postupným prechodom cez Bukovinu a Halič sa valaský živel rozširoval aj o východoslovanské etnikum. Valasi komunikujúci vslovan. dialektmi a vyznávajúci východnú formu krest’anstva prenikajú zo Zakarpatskej Ukrajiny od 14. stor. aj na východné Slovensko. Prechodom cez východoslovenské územie sa jazyk Valachov obohacoval aj o západoslovanské prvky charakteristické pre vsl. nárečia. $\mathrm{S}$ touto jazykovou výbavou prichádzajú Valasi na územie stredoslovenských žúp, kam prinášajú rôzne elementy vsl. nárečí (Habovštiak 1962; Konečný 2012). V prípade strsl. územia je však potrebné prihliadat' na fakt, že Valasi ho osídl'ovali vo viacerých vlnách a prúdoch, a to nielen z oblasti východného Slovenska, ale aj z pol'ských Karpát (Habovštiak 1962: 25). Oblast' Gemera je v rámci bývalých strsl. žúp zároveň prvým kontaktným miestom s valaským živlom prichádzajúcim v 15. stor. z východného Slovenska. Z dia-

\footnotetext{
${ }^{6}$ Viac pozri v Habovštiak $(1962,1970)$.
} 
lektologického hl'adiska je zaujímavé, že okrem výskytu vsl. prvkov nachádzame v miestnych nárečiach aj rezíduá ukr. pôvodu. Tie môžeme zaznamenat' v celej pomedznej stredoslovensko-východoslovenskej jazykovej oblasti ${ }^{7}$. Vo východnom cípe Gemera sa dochovalo aj nárečie vslovan. typu, a to vo valaskej obci Pača. Jeho existenciu môžeme vnímat' ako jeden z dôkazov, že medzi miestnymi Valachmi boli početní príslušníci ukrajinsko-rusínskeho etnického živlu (v historických zdrojoch nazývaného termínom Rutheni ${ }^{8}$ ), ktorý v iných kútoch Gemera postupne splynul so slovenským obyvatel'stvom.

$\mathrm{Na}$ odraz jazykových a hospodárskych osobitostí valaskej kolonizácie v toponymii odkazujeme prostredníctvom klasifikácie tvorenej nasledujúcimi kategóriami:

\section{Terénne názvy súvisiace s apelatívnou lexikou} charakteristickou prevalaskú kolonizáciu

1.1. Názvy utvorené z apelatív rumunského pôvodu. V porovnaní s regionálnou apel. lexikou nesie miestna toponymia menej rum. lexikálnych prvkov. Z apel. grúńl grún (demin. grunik) a i., súvisiaceho s rum. nár. apel. gruniu 'kopec, pahorok' (Králik 2015: 186), sa utvorili názvy Grun̆, Predni grun̆, Zadni grun̆, Hafurou grunik R, Grún Vl, Grúň a Pod Grúňom G. Terénny názov Cihlina Vl súvisí s apel. sihlina s významom 'vlhký pozemok' alebo 'mladý ihličnatý porast' (SSJ 4: 77), odvodeným od apel. sihla 'vlhké miesto v teréne' (HSSJ 5: 252), 'mladý, slabo vyvinutý ihličnatý porast na lúke' (SSJ 4: 77). Podl'a L'. Králika (2015: 530) sa uvažuje o prevzatí z rumunčiny (sihlă 'mladý hustý les', a to pravdepodobne zo slovanského *sъch-lъ 'niečo zoschnuté; (suché) vetvy ap.'), resp. aj o predslovanskom či domácom pôvode slova. S týmto apelatívom sa stretávame aj v pol'skom (sihła), ukrajinskom (сигла), ruskom (сигла) a v českom jazyku (v oblasti Valašska silha 'les' či sihla 'vlhká louka nevhodná pro pasení, mokřina na poli') (ESUM: 225; Machek 1971: 542-543; Kazmír 2001: 318). Daný výraz sa dáva do súvisu aj s mad'. apel. szikla 'skala' či s lotyšským siklis 'nevel'ké bahno, močiar v lese' (ESUM: 225-226). Apel. sihla (a i.) teda prekračuje územie Karpát, avšak so sémantikou 'les, mladý hustý les, ihličnatý porast' sa podla analyzovaných zdrojov stretávame iba v karpatskom geograficko-jazykovom priestore.

1.2. Názvy utvorené z apelatív slovanského pôvodu, ktorých výskyt a frekvenciu podnietila valaská kolonizácia. Ide o názvy, ktoré sa vzt’ahovali na geograficky vyššie položené objekty využívané Valachmi na hospodárske účely (Habovštiak 1962, 1970; Krško 2001). Medzi apelatívami slovanského pôvodu, ktorých frekvencia na našom území narástla prostredníctvom valaskej kolonizácie, nachádzame v skúmanej oblasti:

\footnotetext{
7 Pozri Habovštiak 1962: 22-25.

8 Pozri Štec 1992: 9, Ratkoš v: Habovštiak 1962: 19.
} 
— apel. prieslop, t. j. príslop 'plytké vysokohorské sedlo’9 (Králik 2015: 474), etymologicky zrejme súvisiace s nár. slop 'jama na ceste (po daždi plná vody)', resp. слап 'волна', 'яма в каменном русле реки, куда свысока падает вода' (Králik 2015: 474; Uhlár 1980: 215; Grigorjan, w: Murzaev 1984: 460), ktoré dokladujú terénne názvy Prieslop a Pot Prịeslop R; terénne názvy utvorené z geografického termínu príslop (a i.) nachádzame v „karpatoruských" ${ }^{\text {“10 }}$ obciach (Petrov 1929: 130, 197), v bulharskej, rumunskej a českej (najmä moravsko-sliezskej) toponymii (Murzaev 1984: 460; GeoP), v Macedónsku, v juhovýchodnom Pol'sku (GeoPP) a v súvislosti s koreňom slop- aj v toponymii Slovinska a lužickosrbskej oblasti (Šmilauer 1970: 163);

— apel. čeršl’a, t. j. črchl’a (kršlla a i.) 'vyčistené, vyklčované miesto, upravené na lúku alebo pasienok', gem. šeršla 'preriedená mladá hora', a to zo slovesa črchlit', kršslit' a i. 'obsekávat', lúpat' kôru zo stromu, aby vyschol', potom 'vytínat' očrchlené stromy' a následne 'klčovat' (Majtán 1996: 67; Orlovský 1982: 327), z psl. *čbrxl'a, *čbrxlb (ESSJ 4: 147), ktoré sa proprializovalo do názvu Čeršl’a R; s názvami utvorenými z apel. črchl'a, kršlla (a i.) sa môžeme stretnút’ v „karpatoruských" obciach (Petrov 1929), v karpatskej časti Moravy a Sliezska (GeoP), v juhovýchodnom Pol'sku (GeoPP), pričom ESSJ 4 (147) dokladá ich výskyt aj v srbsko-chorvátskej toponymii;

- apel. pol'ankalpolänka, teda demin. podobu apel. pol'ana (z psl. *poljana) s významom 'horská lúka, lúka v lese' (SSN 2: 943), ktoré sme v toponymii zachytili v podobách Pol’anki R, Polänka, Nat Polänkou Vl; porovnajme české apel. polana 'náhorná paseka, lúka alebo pole, náhorná planina' (Machek 1971: 469); ukr. поляна 'rozl'ahlé pole, rúbanisko, lúka' (MNS: 694); s toponymami typu Pol'ana (a i.) sa môžeme stretnút' takmer v celom slovanskom jazykovom priestore, pričom podl'a V. Šmilauera (1970: 145) sa lexéma pol’ana vo význame 'lúka v lese’ vyskytuje v apel. lexike Slovenska, Bulharska, Macedónska, Česka, Pol’ska, Bieloruska, Ukrajiny a Ruska;

- okrem uvedených termínov horskej nomenklatúry sem zarad'ujeme aj apel. košărisko, 'miesto, kde bol košiar ${ }^{11}$ ' (SSN 1: 840), odkazujúce na hospodárske preja-

9 V. Uhlár (1980) pripisuje názvom typu Príslop sémantiku 'vrch nad slopom (sedlom, úžlabinou)'. Ich využitie pri pomenúvaní úžlabín/sediel medzi vrchmi hodnotí ako spätné (metonymické) posúvanie významu.

${ }^{10}$ Týmto termínom autor pomenúva obce bývalých uhorských stolíc v oblasti Podkarpatskej Rusi — ako súčasti rozsiahlejšieho „karpatoruského“ územia — t. j. Marmarošskej, Ugočskej, Berežskej a čiastočne Užskej župy (ktoré v súčasnosti ležia na území Ukrajiny, čiastočne Mad’arska, Rumunska a v prípade Užskej župy aj Slovenska), ale aj Zemplínskej, Šarišskej a Spišskej župy na území Slovenska (Petrov 1929: 2*).

${ }^{11}$ L. Králik spája apel. košiar s psl. *košarz a uvádza, že „,novší význam, ohrada pre ovce «vznikol z pôvodného» ohrada z prenosných dielcov (pletených z prútia na spôsob koša), zrejme v súvislosti s pastierskymi migráciami v Karpatoch“ (Králik 2015: 293). Pozri aj výklad slova *košara / *košarz / *košerb (ESSJ 11: 183-185). 
vy valaského živlu; nachádzame ho v terénnych názvoch Na košariska $\mathrm{R}$, Košäriská V1 a Na Košáriská NS; toponymá utvorené z apel. košarisko (košařisko, komapume a i.) sme zaznamenali aj v ,karpatoruskej“ (Petrov 1929: 175) a v pol'skej toponymii (Podkarpatské, Malopol'ské a Sliezske vojvodstvo (GeoPP)), ako aj v karpatskej časti Moravy a Sliezska (GeoP). Toponymá súvisiace s psl. apel. košara (a i.) vo význame 'ohrada pre ovce, dobytok' sú však rozšírené aj v iných slovanských krajinách ležiacich v priestore karpatsko-balkánskeho horského pastierstva a známe sú aj v Rusku (Šmilauer 1970: 97).

2. Terénne názvy utvorené z antroponým spätých s valaskou kolonizáciou

2.1. Valaskú kolonizáciu regiónu možno doložit' aj prostredníctvom názvov utvorených z antroponým neslovenského, najmä rusínsko-ukrajinského pôvodu. Do tejto kategórie môžeme zaradit' názov Maksinka/Maksimka VS, ktorý súvisí s o. m. Maxin, Maxim (ukr. Maксuм; porovnajme o. m. Szabados Maxin v Pači (Ila 1946: 155)). V Rejdovej nachádzame názvy Petrenkouna rovienka, z o. m. Petrenko (ukr. Петренко s antropoformantom -енко), Klimentou a Pret Klimentou, z o. m. Kliment, ukr. Климент (v Rejdovej sme zachytili o. m. Klima utvorené z vslovan. podoby krstného mena Kliment preniknuvšej aj do staršej slovenčiny 'v čase príchodu krest'anstva na naše územie z východného krest'anského prostredia' (Majtán 2014: 67)). Na ukrajinsko-rusínsky (prípadne aj pol'ský) pôvod miestneho obyvatel'stva odkazujú aj názvy Leškova jama a Lešková studňiška G súvisiace s o. m. Leško (dodnes sa vyskytujúcim vo Vlachove), ktoré bolo utvorené z о. m. Лесь, Олесько (< Олекса, Олександр), prípadne zo slovanského mena Лех (< Льстиславъ). Priezviská Лешко, Лешка а i. sú typické pre západné časti Zakarpatskej Ukrajiny; о. m. Лешко sa uvádza aj v slovníku vlastných (osobných) mien v lemkovskom dialekte ako nár. variant o. m. Олекса (Pirtej 2001: 456), časté je však aj v Pol'sku (Čučka 2011: 218).

2.2. Medzi terénnymi názvami utvorenými z antroponým nachádzame aj osobné mená naznačujúce etnický pôvod obyvatel'stva. Ide o názvy: U Rusnáka prịelox V1, súvisiaci s menom domu U Rusnáka, a to z o. m. Rusznak (Ila 1946: 139-140), ktoré vzniklo transonymizáciou $\mathrm{v}$ súčasnosti neoficiálneho variantu etnonyma Rusín (Rusnák), latinsky Ruthenus (tento termín však nemusí v zásade vyjadrovat' iba etnickú príslušnost ${ }^{12}$ ); Oloxoua jama $\mathrm{R}$ a Oloxová zem $\mathrm{V}$, utvorené z o. m. Oloch (Ila 1946: 139), a to z mad'. oláh ('Rumun'), ktorý sa utvoril z juhoslovanského vlach (Machek 1971: 413); na prítomnost' pol'ského elementu, ktorý sem mohol počas valaskej kolonizácie preniknút' napríklad z oblasti pol'skej Haliče, odkazuje terénny názov Poläčki NS utvorený z o. m. Polyacsek (Ila 1944: 49), resp. aj Polak (nár. Poläk), ktoré B. Ila (1944: 47) zachytáva aj v miestnej antro-

\footnotetext{
12 Podrobnejšie pozri Ratkoš w: Habovštiak 1962: 19.
} 
ponymii v záverečnej fáze valaskej kolonizácie regiónu, ktorá trvala v rozmedzí 15.-17. stor. (so striedaním $k / \check{c}-$ Poläk $>$ Poläčki).

V súvislosti s kategóriou č. 2 treba uviest', že tento typ terénnych názvov možno považovat' iba za nepriamy dôkaz o nedomácom pôvode obyvatel'stva. Pri hodnotení etnickej príslušnosti treba zároveň akcentovat' konštatovanie E. Krasnovskej, „že v menách ukrajinského [a iného — pozn. autora] pôvodu sa už napr. aj v 18. stor. nemusel pocit'ovat' príznak etnicity, že tu išlo vlastne o rodinné meno slovenského, domáceho obyvatel'a, teda vlastne o osobné meno akoby už «odapelativizované»" (Krasnovská 1991: 143).

3. Terénne názvy utvorené z apelatív domáceho pôvodu odkazujúcich na typické hospodárske prejavy valaského živlu

Súvislost's hospodárskymi aktivitami Valachov naznačujú terénne názvy Mraznica R, VS (< mraznica 'zimná stajňa alebo zimovisko pre ovce vybudované na horských lúkach' (Podolák 1982: 124)) a čiastočne aj Pastirska R (< pastier, nár. pastir; na konkrétnejšie označenie pastierov oviec sa $\mathrm{v}$ tejto oblasti používa apel. juhas/juhás). Isté konotácie však možno nachádzat’ aj v názvoch odkazujúcich na kultiváciu prírodného prostredia pri získavaní pasienkov (typu Ždžar R, Paseki VS a pod.).

\section{ZO SLOVENSKO-MAĎARSKÝCH ETNICKÝCH A JAZYKOVÝCH KONTAKTOV V TOPONYMII}

Gemerský región je priestorom, ktorým aj v súčasnosti prechádza slovensko-mad'arských etnická a jazyková hranica deliaca región na slovenský sever a mad'arský juh. V Slanskej doline sa slovensko-mad’arská jazyková hranica nachádza medzi Betliarom a Nadabulou (mestská čast' Rožňavy).

Mad’arské etnikum sa objavuje v európskom priestore v 9. stor., pričom v Karpatskej kotline sa usídl'uje v priebehu 10. stor. (Pintérová 2007). Na území Gemerskej župy, ktorá sa vyformovala v priebehu 13. stor., možno v danom historickom období hovorit' o čiastočnej slovensko-mad’arskej symbióze, a to predovšetkým na juhu regiónu (Marsina 1991), čo možno podopriet’ aj lingvistickým výskumom. Vzhl'adom na neprítomnost' toponým s nosovkou sa J. Stanislav (1948) domnieva, že v južnom Gemeri sa Mad'ari usadili až po 10. storočí. Existencia mad'. názvov zachovávajúcich staršie slovanské $g$ však naznačuje prítomnost' Mad'arov ešte pred 12. stor. (Stanislav 1948). V priestore horného Gemera (na sever od Plešivca) sa výrazné stopy po Mad'aroch objavujú v listinách z 13. stor., avšak neprítomnost' názvov so starším $g$ naznačuje mad’arské osídl'ovanie až po konsonantickej zmene $g>h$ prebehnuvšej v 12. stor. (Kniezsa, w: Stanislav 1948). Podl'a R. Marsinu 
(1991) nadobudla slovensko-mad'arská etnická hranica v Gemeri približne dnešnú podobu asi už v 13., najneskôr však v 14. storočí.

Prvky odkazujúce na existenciu mad’arsko-slovenských jazykových a etnických kontaktov zaznamenávame aj v skúmanej toponymii. Na základe navrhnutej klasifikácie môžeme dané terénne názvy začlenit’ do týchto kategórií:

\section{Terénne názvy utvorené z apel. lexiky mad'arského pôvodu}

1.1. Prvá podkategória zahŕn̆a terénne názvy súvisiace $\mathrm{s}$ apelatívami, ktoré netvoria súčast' lexiky vgem. nárečí. Ide o názvy utvorené $\mathrm{z}$ mad'. apelatív: kert ${ }^{13}$ ('záhrada') > Kert Vl (miestna čast' Vlachova, v ktorej sa pôvodne nachádzala grófska záhrada s rybníkom); tag ( 'parcela, kus pol’a/lánu’) > Učitelou Tak, Fararou Tak VS, Tak, Nat Tagom, Pot Tagom NS; tan̆a ${ }^{14}$ ('gazdovská usadlost' na samote, rol'nícky príbytok' (SSJ 4: 491), z mad'. tanya 'usadlost', samota; salaš') > Taňa G; kápolna ('kaplnka', a to zo stredovekého latinského cappella (Králik 2015: 255)) > Na Kápolen ${ }^{15}$ NS (prvý záznam máme až z roku 1974 v podobe Kápolni (Orlovský 1974)) a pravdepodobne aj Kapoven VS; z mad'. apelatív só ('sol") a jó (staromad'. 'rieka'; t. j. folyó) sa utvorilo kompozitum Šäjóu V1, Šajou G, Šajóu NS; ide o mad'. pomenovanie rieky Slaná rozšírené v živej toponymii (porovnajme aj variant Šajava (Orlovský 1982: 322), ktorý sa podl'a B. Varsika (1990) začal používat' v 19. stor. pri strednom toku rieky vplyvom mad'. názvu Sajó známeho v pomad'arčenom okolí Rožňavy). Najstarší záznam pochádza z roku 1200, ked' sa uvádza ako Souyoy, Souyou (Sičáková 1996: 74). Pôvod tohto názvu zaujal pozornost' viacerých lingvistov a historikov. B. Varsik (1990: 88) hovorí o staromad'. Só-

${ }^{13}$ Mad'. apelatívum kert sa v rámci slovenského jazykového územia stalo súčast'ou vsl. nárečí, kde nadobudlo podobu kerta (fem.) s významom ‘záhrada (obyčajne v mestách)“ (SSN 1: 765). Do oblasti gem. nárečí však toto apelatívum nepreniklo. Na základe jazykovej situácie v regióne predpokladáme, že mad'. apel. kert (ktoré sa proprializovalo so zachovaním mad’. morfologickej štruktúry) preniklo do miestnej toponymie sprostredkovane, a to prostredníctvom šlachty mad'arskej národnosti (rod Andrášiovcov).

${ }^{14}$ J. Orlovský (1982) apel. taňa v gem. nárečiach nezachytáva a prostredníctvom terénneho výskumu sa ani nám nepodarilo doložit' jeho existenciu.

${ }^{15}$ Objekt sa nachádza v blízkosti miestneho cintorína. V miestnom nárečí sa apel. kápolnalkápolen (a vôbec kaplnka) nepoužíva, čo súvisí s cirkevnými pomermi v danej oblasti (známe sú iba zriedkavo používané podoby kápliška Vl, kaplička VS). J. Orlovský (1982: 128) uvádza v oblasti stredného Gemera apel. káplnka, v gem. toponymii sa však často stretávame s tvarmi Kápóna, Kápolna, Kápolni, Kápouná (Krško 2001: 134; Orlovský 1982: 128). Dané príklady z gem. toponymie naznačujú súvis s mad'. apel. kápolna (avšak s uplatnením hláskoslovnej a slovotvornej adaptácie). Podoba Kápolen teda reprezentuje v skúmanej oblasti výhradne propriálny priestor (so zmenou formantu -na >-en, ktorá je vo východnom Gemeri pomerne frekventovaná, tak v apelatívnej, ako aj v propriálnej sfére, napr. Šetiéren Vl, Halen R (v. v.)). V prípade názvu Kapoven (VS) však nemožno vylúčit' ani súvislost's historickým apel. kap (psl. *kapъ 'pohanská modla, soška obyčajne v podobe tváre jedného z pohanských bôžikov' (Krajčovič 2005: 115)). 
jó, t. j. só folyó ('slaná rieka'), ktorý 'vznikol prekladom z pôvodného slovenského názvu Slaná’.

1.2. V skúmanom súbore nachádzame aj lexémy mad'. pôvodu tvoriace integrálnu súčast' apel. lexiky miestnych nárečí. Ide o lexémy: mertuk (v HSSJ 2 mertuk, gem. 'miera' (Orlovský 1982: 176), z mad'. merték 'miera, rozmer', vzhl'adom na pomenúvanie v teréne 'hraničný znak' (HSSJ 2: 289)) > Mertuki Vl; capáš (nár. aj čapáš; 'priechod medzi pol’ami, ktorými sa ženie dobytok na pašu, výhon, priehon' (SSN 1: 235), z mad'. csapás 'lesný chodník vyšliapaný zverinou') > Capaš R, Capáš Vl; šetiéren ('nádrž na vodu privádzanú potrubím', z mad'. csatorna 'kanál, žl'ab, stoka') > Šetiéren Vl (miestna čast'); bereg/k ('lúka, kde stojí voda' (Orlovský 1982: 26), z mad'. berek 'trasovisko, slatina, zamokrená lúka, tŕstie' a pod. (Bába i Nemes 2014: 89-90)) > Bereki NS; ortaš ('klčovisko', z mad'. irt 'klčovat', gem. ortovat/-č (Orlovský 1982: 218)) > Ortaš, Pod Ortaš VS; dadou (gem. 'detská opatrovňa, škôlka' (Orlovský 1982: 54; SSN 1: 289), porovnajme mad'. dada 'pestúnka') > Dadou VS (miestna čast'); ako prevzatie z mad'arčiny sa hodnotí aj apel. xotár/kotár (> adj. xotárni), z mad'. határ 'hranica' (< hat 'byt' schopný; ovládat'; prenikat' niekam' a pod. (Králik 2015: 222) ${ }^{16}$; gem. 'územie patriace do katastra obce', 'hranica medzi katastrami obcí' (SSN 1: 676); v toponymii sa uplatnil druhý význam) > Ot xotara VS, Do Xotára G, Do Kotárä, Nat Kotárom, Xotárna dolka, Xotární potuók $\mathrm{Vl}$.

\section{Terénne názvy utvorené z antroponým mad’arského pôvodu}

Na základe doterajšieho výskumu sem zarad’ujeme terénne názvy Ďurd'oụa, Nad Durd'ouou R (ide o mad'. podobu mena Juraj - György; porovnajme o. m. Gyurd, Giuro-Giörgi (Ila 1944, 1946)); Xajnalou, Pot Xajnalou, Nat Xajnalou R (z o. m. Hajnal < mad'. hajnal 'úsvit'; bez záznamu v skúmanej oblasti); Kenderoua, Pot Kenderounou R (z o. m. Kender < mad'. köndör 'kučeravý', v nárečí Rejdovej kenderiui; porovnajme o. m. Kender Palička (Kolesár 2013: 31)); Antalova dolinka VS (z o. m. Antal (Ila 1944: 296), mad'. podoby mena Anton), Hajdúkovo/Hajdúková Vl (z o. m. Hajdúk, so starším variantom Hajdu (Ila 1946: 139) < mad'. hajdú 'dráb, pešiak, žoldnier pre hraničnú službu', gem. aj hajdúk 'lesný hájnik, horár'). V Nižnej Slanej nachádzame banské štôlne s názvami Gejza (mad'. Géza) a Manó (stará mad'. demin. podoba o. m. Mánuel, Emanuel).

Predstavená analýza živej toponymie skúmaných obcí nás nabáda k akcentovaniu prínosu skúmania propriálneho, $\mathrm{v}$ našom prípade toponymického priestoru pri poznávaní etnokultúrnych aspektov determinujúcich historický hospodársky a jazykový vývin vybranej oblasti. Lexikálno-sémantická výstavba miestnych te-

16 Odlišný názor v súvislosti s pôvodom tohto apelatíva zastáva Š. Ondruš (2004: 135-136), ktorý ho spája s psl. slovesom chetati, chentati vo význame 'chodit', čo podopiera tvrdením, že hranice/územia osád sa určovali 'chodením, obchádzaním územia'. 
rénnych názvov ponúka pomerne bohatý počet prvkov odkazujúcich na prítomnost' nem. banských kolonistov v regióne, ako aj viacero dokladov na kultúrne a jazykové kontakty s etnicky zmiešaným valaským živlom a s mad’arským etnikom. Dané prvky súvisiace so skúmanými etnikami sa objavili v toponymii všetkých východogemerských obcí.

\section{ZOZNAM BIBLIOGRAFICKÝCH, KARTOGRAFICKÝCH A INÝCH ODKAZOV}

Az második katonai felmérés. Die zweite militärische Vermessung. Kartenprofilen des Königreisch Ungarn und Banat von Temes (1806-1869), 2005, Arcanum, Budapest (DVD).

Bába B., Nemes M. 2014: Magyar földrajzi köznevek tára, Debreceni Egyetemi Kiadó, Debrecen.

Čučka P. P. 2011: Slov'âns'ki osobovi imena ukrajinciv: Istoriko-etimologičnij slovnik, Lira, Užhorod.

Ďurčo P. i in. 1998: Databáza vlastných mien a názvov lokalit na Slovensku. Databáza priezvisk na Slovensku, Jazykovedný ústav L. Štúra SAV, Bratislava, http://slovniky.korpus.sk (prístup 09.10.2016).

Habovštiak A. 1962: Vplyv valašskej kolonizácie na stredoslovenské nárečia, „Jazykovedný časopis“ 1, s. 8-27.

Habovštiak A. 1970: Oravské chotárne názvy, Stredoslovenské vydavatel'stvo, Banská Bystrica.

Horváthová M. 2002: Nemci na Slovensku. Etnokultúrne tradicie z aspektu osídlenia, remesiel a odievania, Lilium Aurum, Dunajská Streda.

Ila B. 1944-1946: Gömör megye. II.-III. kötet, A Magyar Tudományos Akadémia Kiadása, Budapest.

Kazmír S. 2001: Slovník valašského nářečí, Nakladatelství Dalibor Malina, Vsetín.

Kolesár J. 2013: Rejdová. Monografia obce, Agentúra Sáša Košice, s. r. o., Košice.

Konečný S. 2012: Historické kontexty formovania a vývoja rusínskeho etnika v Karpatoch, [v:] A. Duleba (red.), Rusíni na Slovensku, ADIN, s. r. o. Prešov, Bratislava-Prešov, s. 34-42.

Kott F. Š. 1906: Třetí př́spěvek k česko-německému slovníku, zvláště grammaticko-fraseologickému, nákladem České akademie císaře Františka Josefa pro vědy, slovesnost a umění, Praha.

Krajčovič R. 2005: Živé kroniky slovenských dejín skryté v názvoch obcí a miest, Literárne informačné centrum, Bratislava.

Krajčovič R. 2007: Z lexiky stredovekej slovenčiny s výkladmi názvov obci a miest, „Kultúra slova“ 41, č. 2, s. 84-91.

Krajčovič R. 2009: Z lexiky stredovekej slovenčiny s výkladmi názvov obci a miest, „Kultúra slova“ 43, č. 1, s. 27-34.

Králik L'. 2015: Stručný etymologický slovník slovenčiny, Veda, Bratislava.

Krasnovská E. 1991: Osídlenie východného Gemera vo svetle osobných mien, [v:] M. Majtán (zost.), X. slovenská onomastická konferencia. Bratislava, 13.-15. 9. 1989. Zborník referátov, Jazykovedný ústav L'udovíta Štúra SAV, Bratislava, s. 138-146.

Krško J. 2001: Terénne názvy z Muránskej doliny, FHV UMB, Banská Bystrica.

Krško J. 2008: Nemecké kolonizačné vplyvy na hydronymiu povodia Hrona, „Acta onomastica“ IL, s. 203-211.

Machek V. 1971: Etymologický slovnik jazyka českého, Academia, Praha.

Majtán M. 1996: Z lexiky slovenskej toponymie, Veda, Bratislava.

Majtán M. 2014: Naše priezviská, Veda, Bratislava.

Marsina R. 1991: Najstaršie miestne názvy a osídlenie Gemera, [v:] M. Majtán (zost.), X. slovenská onomastická konferencia Bratislava 13.-15. septembra 1989. Zborník referátov, Jazykovedný ústav Ludovíta Štúra SAV, Bratislava, s. 47-53. 
Murzaev È. M. 1984: Slovar'narodnyh geografičeskih terminov, Mysl', Moskva.

Ondruš Š. 2004: Odtajnené trezory slov III, Vydavatel'stvo Matice slovenskej, Martin.

Orlovský J. 1974: Chotárne názvy z Gemera, „Obzor Gemera“ 5, č. 2, s. 70-74.

Orlovský J. 1982: Gemerský nárečový slovník, Osveta, Martin.

Petrov A. L. 1929: Karpatoruské pomistní názvy z pol. XIX. a z poč. XX. st., nákladem České akademie věd a umění, Praha.

Pintérová B. 2007: Príchod Mad’arov do Karpatskej kotliny vo svetle archeologických prameňov, „Acta Nitriensiae. Zborník Filozofickej fakulty Univerzity Konštantína Filozofa v Nitre“ 9, s. 128-144.

Pirtej P. S. 2001: Slovnik lemkivs'koji govirki: Materìali dlâ slovnika, Legnica-Wrocław, http://www. lemko.org/pdf/Pyrtej2001 (prístup 09.10.2016).

Podolák J. 1982: Tradičné ovčiarstvo na Slovensku, Veda, Bratislava.

Protocollum Visitationis Ecclesiarum Canonice 1802-1804, rkp. v archíve ev. a v. farského úradu Revúca.

Protocolon Petschelianum 1670-1713, rkp. v archíve ev. a v. farského úradu Revúca.

Regel K. 1868: Die Ruhlaer Mundart, Hermann Boehlau, Weimar.

Sičáková L. 1996: Hydronymia slovenskej časti povodia Slanej, Pedagogická fakulta v Prešove UPJŠ v Košiciach, Prešov.

Stanislav J. 1948: Slovenský juh v stredoveku I. diel, Neografia, Turčiansky Sv. Martin.

Šmilauer V. 1970: Př́ručka slovanské toponomastiky, Academia, Praha.

Štec M. 1992: Rusíni či Ukrajinci?, Zväz Rusínov-Ukrajincov ČSFR, Prešov.

Štefaňak O. 2009: Relov a Hágy v premenách času, Obecný úrad Rel'ov, Rel'ov, http://www.relov.ocu. sk/index.php?ids=7 (prístup 09.10.2016).

Š̈̈le P., Šüle P. ml. 2005: Encyklopédia miest a obci Slovenska, PS-LINE, Lučenec.

Uhlár V. 1980: Príslop, slop, prieval, priehyba, „Slovenská reč“ 45, č. 4, s. 213-218.

Valiska J. 1980: Nemecké nárečie Dobšinej, Gemerská vlastivedná spoločnost', Rimavská Sobota.

Varsik B. 1990: Slovanské (slovenské) názvy riek na Slovensku a ich prevzatie Mad'armi v 10.-12. storoči (Príspevok k etnogenéze Slovákov), Veda, Bratislava.

Žilák J. 1980: Chotárne názvy z Gemera a Malohontu vo svetle archívnych dokumentov, „Obzor Gemera" 11, č. 3, s. 174-177.

\section{SKRATKY BIBLIOGRAFICKÝCH, KARTOGRAFICKÝCH A INÝCH ODKAZOV}

DWB - Deutsches Wörterbuch von Jacob Grimm und Wilhelm Grimm, Leipzig 1854-1961, 1971, http://woerterbuchnetz.de/DWB/ (prístup 14.10.2016).

ESSJ 4-11 - O. N. Trubačëv (red.) 1977-1984: Etimologičeskij slovar' slavânskih jazykov. Praslavjanski leksičeskij fond, č. 4-11, Nauka, Moskva.

ESUM - O. S. Mel'ničuk (red.) 2006: Etimologičnij slovnik ukrajins'koji movi, č. 5, Naukova dumka, Kiïv.

GeoP - Geoportál ČÚZK, 2010, Zeměměřický úřad, Praha, http://geoportal.cuzk.cz (prístup 20.11.2016).

GeoPP - Geoportal Krajowy, Główny Urząd Geodezji i Kartografii, Warszawa, 2016 (online: http://www.geoportal.gov.pl/, prístup 20.11.2016).

HSSJ 2-6 - M. Majtán a in. (red.) 1992-2005, Historický slovník slovenského jazyka, zv. 2-6, Veda, Bratislava.

JÚLŠ - Kartotéka terénnych názvov Jazykovedného ústavu L. Štúra SAV.

MNS - E. Želehovskij, S. Nedil'skij 1886: Malorusko-nümeckij slovar, zv. 2, Tov. ìm. Ševčenka, L'vìv. 
SSJ 1-4 — Š. Peciar(red.) 1959-1964: Slovnik slovenskéhojazyka, I.-IV., Vydavatel'stvo Slovenskej akadémie vied, Bratislava.

SSN 1-2 - I. Ripka (ved. red.) 1994-2006: Slovník slovenských nárečí, I-II, Veda, Bratislava.

\section{INÉ SKRATKY}

$$
\begin{aligned}
& \text { Skratky jazykov a nárečí } \\
& \text { franc. } \quad \text { - francúzsky } \\
& \text { gem. } \quad \text { - gemerský } \\
& \text { mad'. - mad'arský } \\
& \text { nem. } \quad \text { - nemecký } \\
& \text { psl. } \quad \text { - praslovanský } \\
& \text { rum. } \quad \text { - rumunský } \\
& \text { rus. - ruský } \\
& \text { spiš. } \quad \text { - spišský } \\
& \text { staromad'. - staromad'arský } \\
& \text { strsl. } \quad \text { - stredoslovenský } \\
& \text { ukr. - ukrajinský } \\
& \text { vgem. - východogemerský } \\
& \text { vsl. } \quad \text { - východoslovenský } \\
& \text { vslovan. - východoslovanský }
\end{aligned}
$$

THE IMPACT OF MULTICULTURALISM ON THE FORM

OF THE LOCAL TOPONYMY (THE CASE OF FIVE EASTERN GEMER VILLAGES)

\section{SUMMARY}

In the paper, we deal with non-standardized geographical names of five Eastern Gemer villages situated in the valley of the river Slaná. The aim of the paper is to analyze geographical names whose lexicalsemantic and formal structure refer to the coexistence of various cultures within the historical development of the described area. The studied area is located on the border of central and eastern Slovakia, near the Slovak-Hungarian ethnic border and in the immediate neighborhood of the German-speaking enclave (Dobšiná). From the economic point of view, the area was affected by the German mining colonization, as well as Wallachian shepherd colonization with the Romanian-Ukrainian ethnic character.

Ke y w ord s: folk toponymy, German mining colonization, Wallachian colonization, Slovak-Hungarian language contacts, Eastern Gemer 